\title{
Molecular Detection and Biological Control of Human Hair Dandruff Causing Microorganism Staphylococcus aureus
}

\author{
Md. Atik Mas-ud" ${ }^{1 \#}\left(\mathbb{D}\right.$, Md Roushan Ali ${ }^{1,2 \#}(\mathbb{D})$, S.M. Zia Hasan ${ }^{1,3 \#}(\mathbb{D}$, \\ Md Ashikul Islam ${ }^{1}$ (D) Md. Faruk Hasan ${ }^{1}$ (D) Md. Asadul Islam \\ and Biswanath Sikdar ${ }^{1 *}$
}

${ }^{1}$ Professor Joarder DNA and Chromosome Research Lab., Department of Genetic Engineering and Biotechnology, University of Rajshahi, Rajshahi-6205, Bangladesh. ${ }^{2}$ School of Life Sciences and Medical Center, University of Science and Technology of China (USTC), 230027 Hefei, Anhui, China. ${ }^{3}$ Department of Neuroscience, School of Medicine, Memorial University of Newfoundland, St. John's, NL, A1C 5S7, Canada.

\begin{abstract}
Human hair dandruff (HHD) is a common unwanted scalp disorder that is prevalent to most human populations all over the world. This study was designed to isolate and characterize pathogens that are responsible for HHD as well as the evaluation of their biological control technique. Isolated bacteria were characterized by different biochemical tests and molecular identification methods. Here, disc diffusion methods were used to determine antibiotic and antibacterial activity against isolated bacteria. The isolated bacterial colonies were found to be Gram-positive, small, round-shaped, and purple. PCR amplification was done using $27 \mathrm{~F}$ and $1492 \mathrm{R}$ primer pairs. A BlastN search of a sequenced 1465 bp region of 16 S rRNA in NCBI GenBank revealed approximately $99 \%$ genome similarity with Staphylococcus aureus. The sequence was deposited in GenBank (Accession No. MH603394). In the antibiotic sensitivity test, Kanamycin showed the highest $31.0 \pm 0.5 \mathrm{~mm}$ diameter zone of inhibition (DZI) against the isolated bacteria. Moreover, as a plant-derived compound, the Methanol extract of Allium sativum revealed the highest, $15.0 \pm 0.5 \mathrm{~mm}$ DZI. The present study would give a promising direction of identification and control of this pathogen biologically.

Keywords: Human hair dandruff, Molecular detection, Biological control, Staphylococcus aureus
\end{abstract}

*Correspondence: sikdar2014@gmail.com; "These authors contributed equally.

(Received: December 03, 2019; accepted: February 06, 2020)

Abbreviations: HHD: Human hair dandruff, LB: Luria and Bertani medium, NA: Nutrient Agar, BLAST: Basic Local Alignment Search Tool, NCBI: National Centre for Biotechnology Information.

(C) The Author(s) 2020. Open Access. This article is distributed under the terms of the Creative Commons Attribution 4.0 International License which permits unrestricted use, sharing, distribution, and reproduction in any medium, provided you give appropriate credit to the original author(s) and the source, provide a link to the Creative Commons license, and indicate if changes were made. 


\section{INTRODUCTION}

Human hair dandruff (HHD) is a common disorder of the skin that affects the scalp and creates an unfavorable condition for most of the people over the world ${ }^{1}$. Dandruff is associated with irritating scalp without swelling and its pathogenesis is composed of numerous intrinsic and environmental factors ${ }^{2}$. Dandruff can contribute to several causes, including dry skin, seborrhea dermatitis, inadequate washing or scrubbing, too often shampoos, scalp psoriasis, eczema, hair-care or yeast-like fungus sensitivity. Scaling and sometimes mild itching are symptoms. Seborrheic dermatitis is a more serious form of the disease, causing skin inflammation ${ }^{2}$. The severity of dandruff varies between mild and severe, where men have higher prevalence and severity ${ }^{3}$.

Bacteria are more critical than fungi to the formation of dandruff, mostly Staphylococcus and Propionibacteria ${ }^{4}$. Xue et al. 2016 reported, Staphylococcus bacterial species are more responsible for the formation of dandruff rather than fungi $i^{5}$. Staphylococcus aureus is grampositive and round-shaped bacteria which are a component of the firmicutes and normal body fluids, mostly seen in the nose, breathing tract and the $\mathrm{skin}^{6-7}$. Evolution of antibiotic-resistant strains of $S$. aureus, for example, methicillin-resistant $S$. aureus (MRSA) that is a global clinical problem ${ }^{4}$. In previously reported studies, staphylococci bacteria are responsible for dandruff pathogenesis. Leong et al., 2019 reported a way to increase the capability of treatments against HDD caused by Staphylococcus ${ }^{8}$.

To address this global issue, plants are considered to be a good source of traditional medicine, as are both bioactive and new therapeutic compounds. The plants are known since ancient times and widely accepted as a crucial source of traditional medicinal compounds for specific diseases diagnosis ${ }^{9}$. There is no previously reported research where the antibacterial activity of plant extracts against human hair dandruff is discussed. We planned to treat this unfavorable scalp disorder for the first time through globally available medicinal plants.

Therefore, this study focused on the investigation of bacterial isolation from a healthy volunteer with dandruff infected hair. And to characterize the pathogen in the aspect of both biochemical and molecular approaches and to characterize the antibacterial activities of plant extracts to control this unpleasant HHD.

\section{MATERIALS AND METHODS Hair samples collection}

In present study, disease-associated hair samples were obtained from a healthy volunteer having a bad experience of this unpleasant scalp disorder who is not a member of our research group and willing to dedicate his unwanted hair scalp infected with dandruff as our research sample. Ethical clearance of the study was approved by the Director of the Institute of Biological Science, University of Rajshahi, Rajshahi-6205, Bangladesh (Approval no. IBSC.EC.5.6.18-00122).

\section{Isolation and culture of bacteria}

The hair sample collected in a sterilized zipper bag, and then hairs were taken in a conical flask that contained $100 \mathrm{ml}$ distilled water. The flasks were shaken in a rotatory shaker for 30 minutes. One milliliter of water was taken into LB liquid medium by using a sterile pipette and incubated to grow bacteria at $37^{\circ} \mathrm{C}$ in a shaker overnight. On the next day, after incubation, a sterile loop was used to streak the bacteria onto a solid LB agar medium. The plated bacteria were cultured and incubated overnight, 16 hours, at $37^{\circ} \mathrm{C}$.

The pure culture was obtained through the streak-plate method. Finally, the plate was incubated overnight at $37^{\circ} \mathrm{C}$. There were many single colonies found on the plates. To obtain the desired microorganism, sub-culturing was done, and the liquid medium was prepared for every single colony. The single colonies were taken by a loop of inoculation needle and touched on LB liquid medium on the laminar flow bench. Then it was incubated for $16-18 \mathrm{~h}$ at $37^{\circ} \mathrm{C}$ temperatures. A loop of an inoculation needle was taken into the single colonies and touched on LB liquid media. It was then incubated at $37^{\circ} \mathrm{C}$ temperatures for 16-18 hours.

\section{Biochemical characterization}

The morphological and biochemical characteristics of the isolated bacteria were done. Bacteriological analysis was performed using selective media ${ }^{10-13}$. After 12 to 16 hours of growth in the LB Agar plate at $37^{\circ} \mathrm{C}$, the morphology of the colony, size, shape, color, and growth patterns 
were recorded. Light microscopy was used to observe cell size. A series of biochemical tests namely, Potassium hydroxide, $\mathrm{H}_{2} \mathrm{~S}$ production, Indole formation, Motility, Catalase, Simmon citrate, Kovac oxidase, Methyl red, MacConkey agar, Kligler Iron Agar(KIA), Triple Sugar Iron (TSI) and Urease tests were performed to characterize the isolated bacteria based on Bergey's Systematic Bacteriology Manual guidelines ${ }^{14}$.

\section{Molecular characterization \\ Extraction of genomic DNA}

Genomic DNA was extracted from bacterial cultures by heat lysis and selective precipitation of cell debris and polysaccharides with Maxwell Blood DNA Kit (Model: AS1010) Promega, USA. The extracted DNA was resuspended in TAE buffer (Promega, USA) and quantified using a NanoDrop Spectrophotometer (Model: ND2000, Origin: Thermo Scientific, USA), and then run $1 \%$ agarose gel electrophoresis to determine the size of the DNA.

\section{PCR analysis}

Amplification of the 16S rRNA gene was performed by conventional PCR technique using the universal primers: $27 \mathrm{~F}$ forward primer 5'TGGTAGTCCACGCCCTAAAC-3' and 1492R reverse primer 5'-GACGGGCGGTGTGTRCA-3'15-16 in a $25 \mu \mathrm{L}$ reaction volume, containing nuclease free $\mathrm{ddH}_{2} \mathrm{O}$ $15 \mu \mathrm{L}$, dNTP mix $1.0 \mu \mathrm{L}$, forward primer $1.0 \mu \mathrm{L}$, reverse primer $1.0 \mu \mathrm{L}$, DNA template $1.5 \mu \mathrm{L}, \mathrm{MgCl}_{2}$ $2.5 \mu \mathrm{L}$, Taq buffer B $2.5 \mu \mathrm{L}$, and Taq polymerase $0.5 \mu \mathrm{L}$. The PCR was done by initial denaturation at $95^{\circ} \mathrm{C}$ for $5 \mathrm{~min} ; 35$ cycles of denaturation at $95^{\circ} \mathrm{C}$ for $40 \mathrm{~s}$, annealing at $65^{\circ} \mathrm{C}$ for $1 \mathrm{~min}$, extension at $72^{\circ} \mathrm{C}$ for $2 \mathrm{~min}$ and the final extension at $72^{\circ} \mathrm{C}$ for $10 \mathrm{~min}$, followed by cooling at $4^{\circ} \mathrm{C}$ until the sample was taken out. Gel electrophoresis was used to visualize the amplified PCR product.

\section{Antibiotic sensitivity test}

A moderate disc diffusion method was applied to measure antibiotic susceptibility ${ }^{17}$. In this research work, to observe the sensitivity pattern against the isolated bacteria, 16 different antibiotics were selected. These isolated bacteria were grown overnight in a nutrient broth at $37^{\circ} \mathrm{C}$ in a shaker with $120 \mathrm{rpm}$ for the antibiotic sensitivity test. Then, $1 \mathrm{ml}$ (CFU $1 \times 10^{6} / \mathrm{ml}$ ) of the overnight culture of bacteria was transferred and gently spread on the nutrient agar plate and dried. Different commercially available antibiotic disks namely, Ampicillin 10 $\mathrm{gg}$, Neomycin $30 \mu \mathrm{g}$, Doxycycline $30 \mu \mathrm{g}$, Kanamycin $30 \mu \mathrm{g}$, Erythromycin $15 \mu \mathrm{g}$, Tetracycline $30 \mu \mathrm{g}$, Cefotaxime

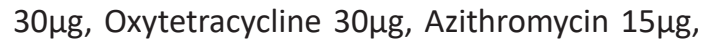

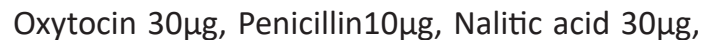
Amoxycillin $10 \mu \mathrm{g}$, Vancomycin $30 \mu \mathrm{g}$, Cefixime $5 \mu \mathrm{g}$, and Rifampicin $5 \mu \mathrm{g}$ per disc were placed over the respective plates ( 1 disk per plate). And then incubated at $37^{\circ} \mathrm{C}$ for 16 hours.

\section{Antibacterial activity of some plant extracts}

Ten diverse plant varieties such as Garlic, Onion, Hog plum, Neem, Fig tree, Cassia, Pathor Kuchi, Bitter Gourd, Ginger, and Sunflower were obtained from various locations of Rajshahi University premises. Different plant parts were used as a potent source of plant extracts, described details in Table 1 . They were carefully rinsed to clean off, air-dried in sunlight for the three days (8 $\mathrm{h} /$ day). And then kept in the shade in an aerated place till drying up completely, and they were pulverized to a fine powder ${ }^{9,18}$. The prepared powder was drenched in Methanol solvents followed by earlier reported an experiment with slight modification (powder to solvent ratio, 1:10, $\mathrm{w} / \mathrm{v}$ ), and incubated for 24 hours at $25^{\circ} \mathrm{C}$ with shaking at $160 \mathrm{rpm}$. Then, the filtrates from the filtration through nylon membrane clothes were dried at $37^{\circ} \mathrm{C}^{19}$. Finally, the dried extracts were dissolved in Phosphate Buffered Saline (PBS) bringing the total volume of $500 \mathrm{ml}$.

The agar disc diffusion method screened the antibacterial activity of the ten plant extracts ${ }^{20}$. A suspension of the inoculum was swabbed uniformly on the solidified $20 \mathrm{~mL}$ LB agar. The

Table 1. Plants name and plant parts (Source of plant extract) used for antibacterial activity

\begin{tabular}{lll}
\hline $\begin{array}{l}\text { Plant } \\
\text { name }\end{array}$ & Scientific name & $\begin{array}{l}\text { Used plant } \\
\text { part }\end{array}$ \\
\hline Garlic & Allium sativum & Bulb \\
Onion & Allium cepa & Bulb \\
Hog plum & Spondias mombin & Fruit \\
Neem & Azadirachta indica & Leaf \\
Fig tree & Ficus carica & Fruit \\
Cassia & Cassia alata & Leaf \\
Pathor Kuchi & Bryophyllum pinnatum & Leaf \\
Bitter Gourd & Momordica charantia & Fruit \\
Ginger & Zingiber officinale & Root \\
Sunflower & Helianthus annuus & Flower
\end{tabular}


inoculum was allowed to dry for $5 \mathrm{~min}$. Aliquot of $10 \mu \mathrm{L}, 20 \mu \mathrm{L}$ and $30 \mu \mathrm{L}$ from liquids crude extract of each plant $(500 \mathrm{mg} / \mathrm{mL})$ was soaked into each $6 \mathrm{~mm}$ Whatman paper discs on the cultured medium and kept in the bench for $1 \mathrm{~h}$ for proper diffusion and after that incubated for $24 \mathrm{~h}$ at $37^{\circ} \mathrm{C}$. The antibacterial activity of the test specimens was evaluated by measuring DZI in millimeter $(\mathrm{mm})$ with a transparent scale after incubation. If the DZI is less than $10 \mathrm{~mm}$, it is considered as resistance. If the DZI is greater than $10 \mathrm{~mm}$ but less than $15 \mathrm{~mm}$, it is considered as intermediately resistant.

\section{Statistical analysis}

For the consistency of results and statistical purposes, all the above-mentioned investigations in this research were carried out three times. The results were analyzed statistically by one-way ANOVA ( Analysis of Variances) as mean and standard error (Mean \pm SE) using Microsoft Excel 2013 version. For the statistical analysis, $\mathrm{P}<0.05$ was considered significant.

\section{RESULTS}

\section{Isolation of pure culture}

After repeated microbial culture of the isolated pathogen in suitable medium and conditions described earlier, pure culture was found. The isolated colony was creamy white (Fig.1A). The colonies were small to medium, smooth, convex, and mucoid in size and shape. The colony morphology was identified by microscopic and visual observation.

\section{Biochemical characterization}

After isolation of the pure culture, various biochemical tests, including gram-staining (noted below) was done to characterize the isolated pathogen precisely. Isolated bacteria confirmed as gram-positive both in gram staining reaction and $\mathrm{KOH}$ solubility test (Fig. 1B). In Sulfide Indole Motility (SIM) test, no gas was produced, no indole ring was found, and motility was observed in media (Fig. 1C). In the case of the Catalase test, bubbles (oxygen gas) were produced immediately after inoculating the bacteria with $\mathrm{H}_{2} \mathrm{O}_{2}$ (hydrogen peroxide), indicated catalase positive. The Simmon's Citrate test showed dark-blue (Prussianblue) color in the inoculating bacterial medium and the bacteria had a positive effect on the citrate medium. Isolated bacteria did not yield a purple color during the Kovac oxidase test. Therefore, it showed a negative result in the Kovac oxidase test. It was less acidic and provided yellow color following inoculation of bacteria into Methyl Red medium so that bacteria had a negative effect on methyl red. For the KIA test, it produced a yellow color on the medium following inoculation of isolated bacteria and showed positive results. For the Urease test and TSI test, negative and positive results were observed respectively by the isolated bacteria. Bacteria produced pink color rounding the colony in MacConkey agar, confirming they are lactose non-fermenting (Table 2).

\section{Antibiotic susceptibility assay}

In antibiotic susceptibility assay, various types of standard discs of antibiotics against the isolated bacteria were used. The highest antibacterial activity was shown by Kanamycin $(30 \mu \mathrm{g} / \mathrm{disc})$ with $31 \pm 0.0 \mathrm{~mm}$ diameter zone of inhibition (DZI) followed by Oxytetracycline (30 $\mathrm{gg} /$ disc) with $28 \pm 0.0 \mathrm{~mm}$ DZI (Fig. 2A). On the contrary,
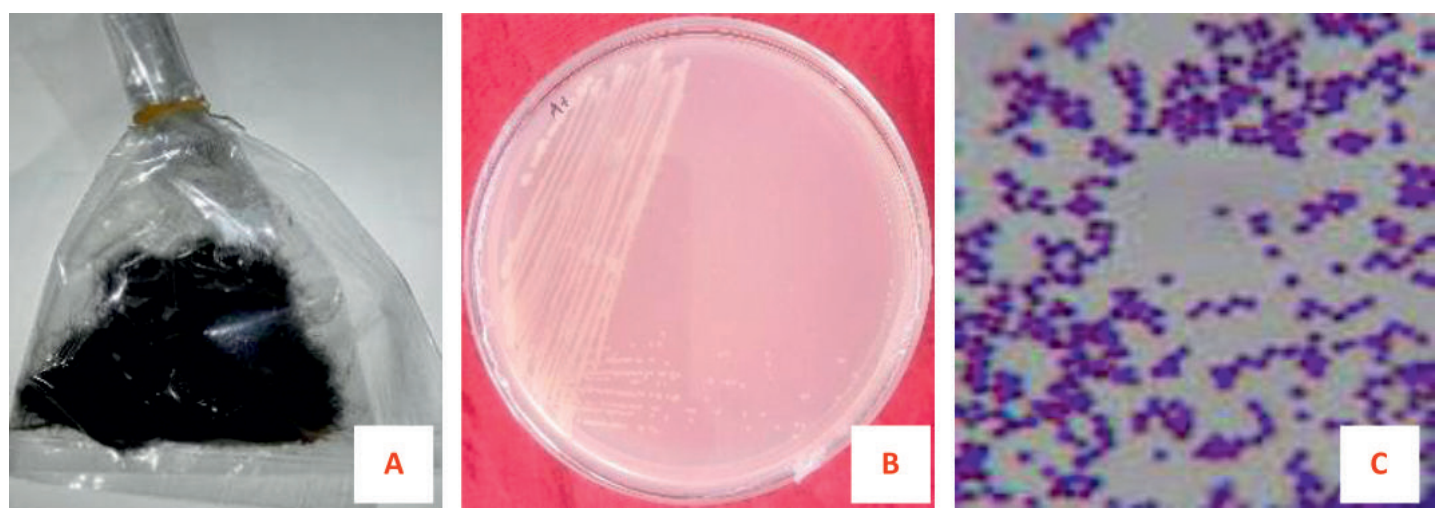

Fig. 1. Collection of hair samples, isolation of bacteria and gram staining of microorganism. (A) Hair sample (B) Isolated bacterial colonies and (C) Gram-positive bacteria 


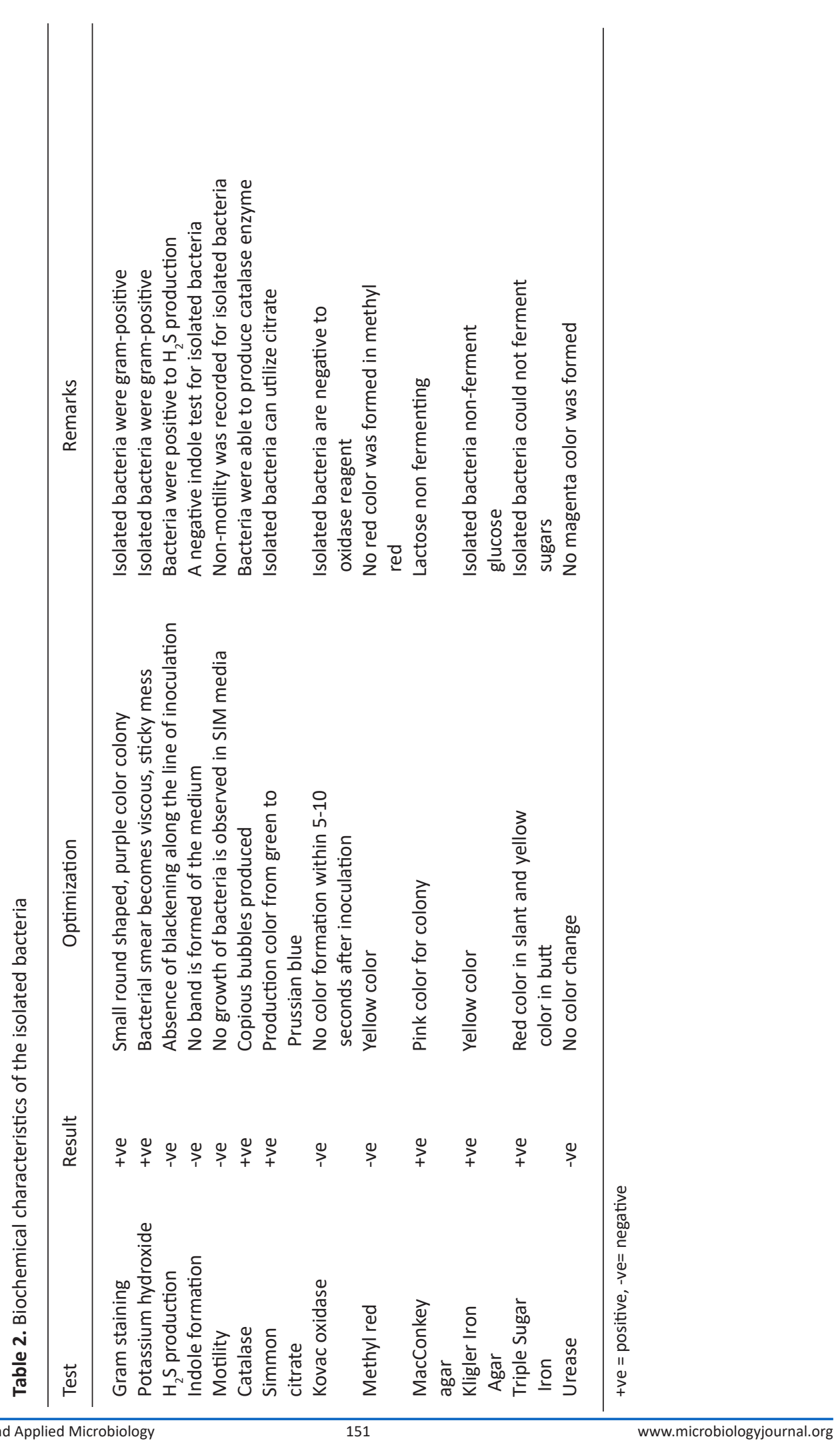


Rifampicin ( $5 \mu \mathrm{g} / \mathrm{disc})$ and Doxycycline $(30 \mu \mathrm{g} /$ disc) showed the lowest; $9.4 \pm 0 \mathrm{~mm}$ and $11 \pm 0.0 \mathrm{~mm}$, DZI. But Ampicillin, Oxytocin, Penicillin, and Vancomycin did not show any zone of inhibition (Fig. 3).

Antibacterial activity against isolated bacteria by some plant extracts

The antibiotics which cause antimicrobial resistance but have some adverse effects on human health. For this reason, the natural products with antimicrobial effects have been investigated to eliminate the use of synthetic antibiotics during the last decades. In recent decades, the use of synthetic antibiotics was replaced by natural products with antimicrobial effects. Therefore, some medicinal plants are used to inhibit the growth of the human pathogenic microorganisms. Among the 10 medicinal plants, the Methanol extract of Allium sativum showed highly significant antimicrobial activity about $15.0 \pm 0.5 \mathrm{~mm}$ DZI (Fig. 4). This study precisely indicates that the antibacterial activity varies with plant type and solvent type.

\section{Molecular characterization}

The genomic DNA of isolated bacteria was PCR amplified by one pair of universal $16 \mathrm{~s}$
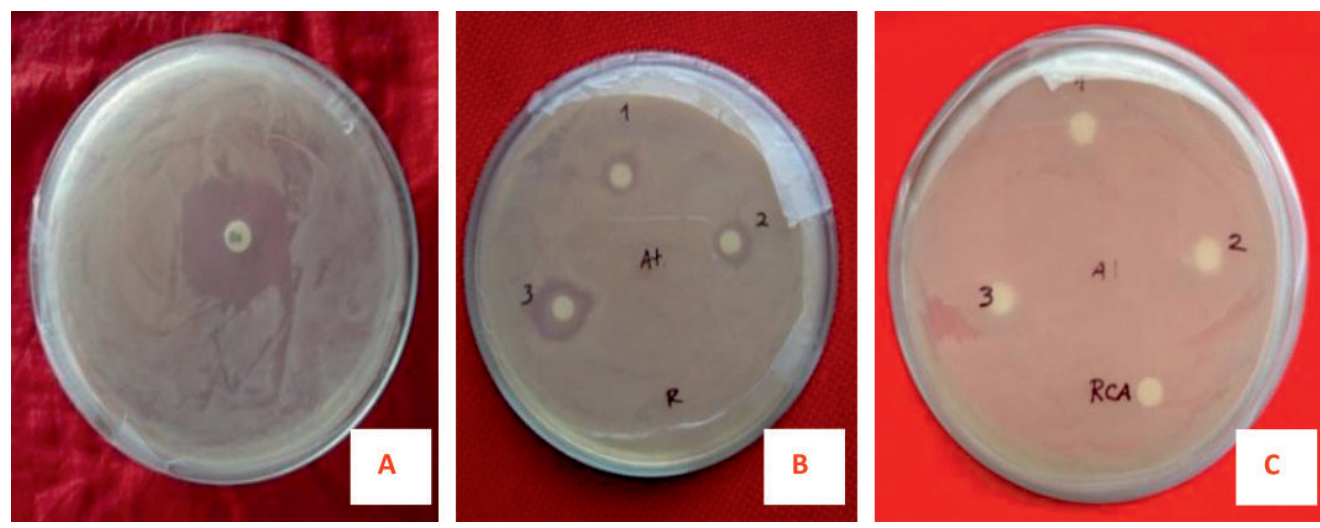

Fig. 2. Antimicrobial activities of drug discs against Staphylococcus aureus. (A) Kanamycin, (B) Allium sativum extract, (C) Rhizobium from Cicer arietinum.

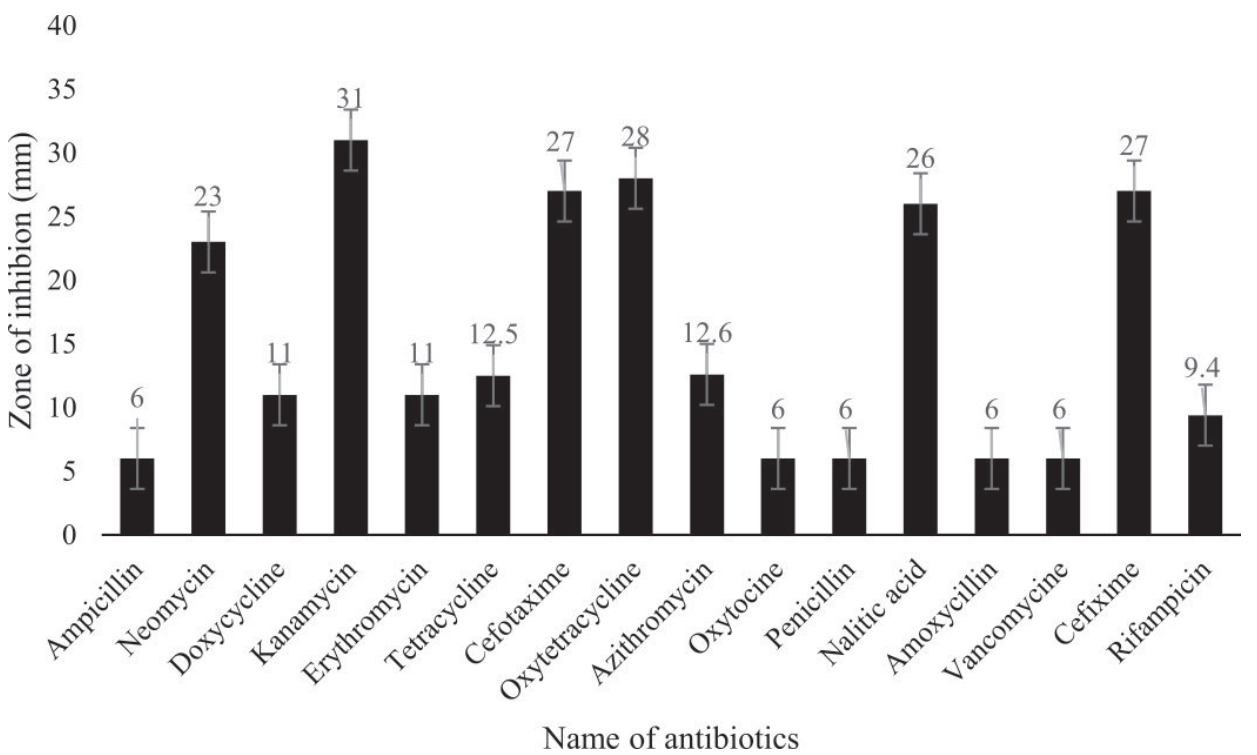

Fig. 3. Graphical representation of antibiotics and their zone of inhibition Legend: $\mathrm{M} \pm \mathrm{SE}=\mathrm{mean}$ and standard error, Resistant $=<10 \mathrm{~mm}$; Intermediate $=10-15 \mathrm{~mm}$; Susceptible=>15 $\mathrm{mm}$ 
ribosomal RNA primers of the genes $(27 \mathrm{~F}$ and 1492R). The PCR amplified fragment was $1500 \mathrm{bp}$ (approximately) compared to the DNA ladder of $1 \mathrm{~kb}$ (Fig. 5).

After sequencing, the 1465 bp nucleotide sequence was performed for a BlastN search in GenBank (https://blast.ncbi.nlm.nih.gov/Blast. cgi). The BlastN result reported approximately
99\% sequence similarity with Staphylococcus aureus strain 8 BWI 16s rDNA gene. The obtained sequence was deposited in GenBank (Accession No. MH603394).

\section{Phylogenetic analysis}

The sequences of Staphylococcus spp. in FASTA format were downloaded from NCBI GeneBank. The data were matched in Multiple

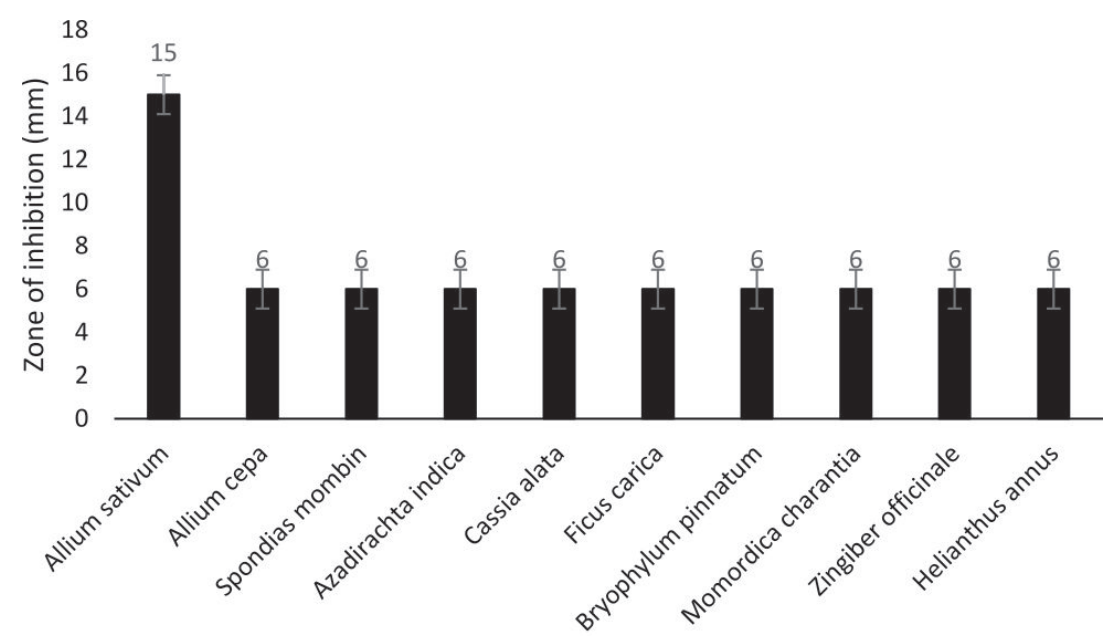

Plant extract name

Fig. 4. Graphical representation of plant extracts and their zone of inhibition

Legend: Mean $\pm S E=m e a n$ and standard error, Resistant $=<10 \mathrm{~mm}$; Intermediate $=10-15 \mathrm{~mm}$; Susceptible=>15 mm

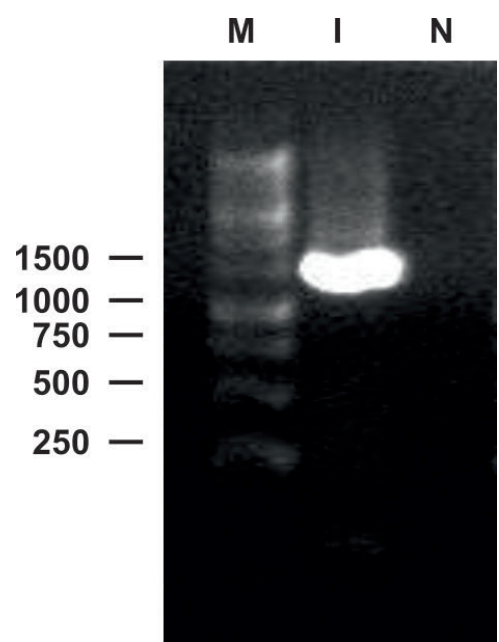

Fig. 5. 16s rRNA PCR profiles of $27 \mathrm{~F}$ and $1492 \mathrm{R}$ primers, generated from bacterial genomic DNA. M: DNA ladder, I: PCR product, N: Negative Control
Sequence Alignment (MSA) and constructed a phylogenetic tree (Fig. 6). The evolutionary tree was constructed using the Unweighted Pair Group Method with Arithmetic mean (UPGMA) method. The tree is drawn to scale with branch lengths that are the same units as the evolutionary distances that the phylogenetic tree is used to infer. Evolutionary steps are determined using the Composite Maximum Likelihood method. Twelve nucleotide sequences were included in the study and eliminated all positions that contain gaps and missing data. In the final dataset, there were 774 positions. Molecular Evolutionary Genetics Analysis (MEGA version 7.0) software was used to analyze the evolutionary studies ${ }^{21-23}$.

\section{DISCUSSION}

Dandruff is a disease of the skin that mainly affects the scalp ${ }^{2}$. The actual cause of this 


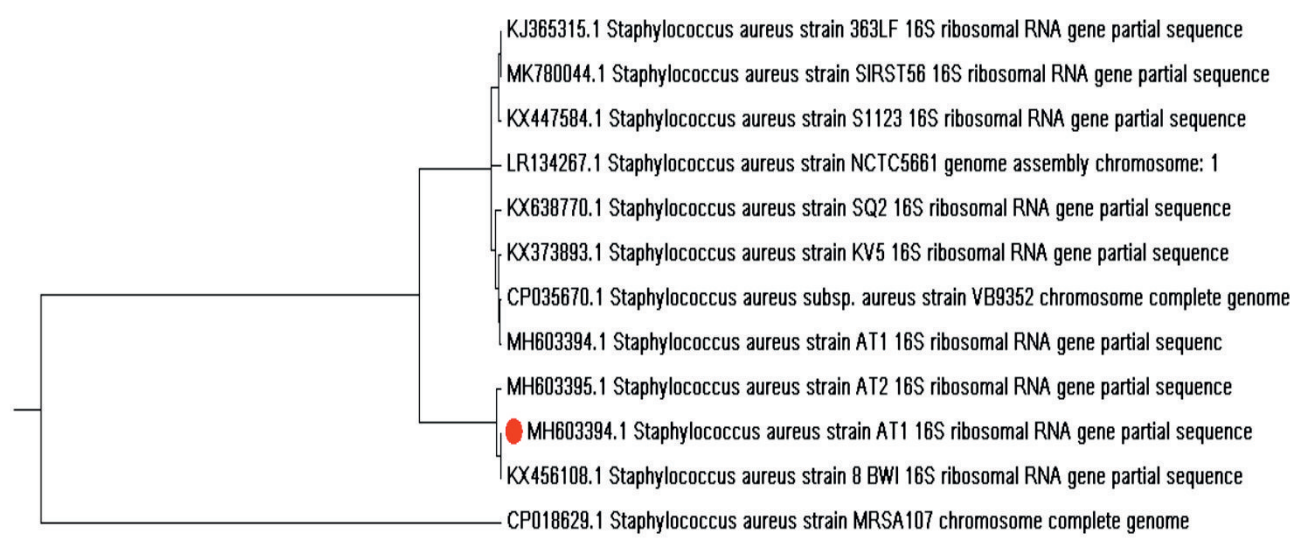

$\frac{1}{0.65} 0.600 .550 .500 .450 .400 .350 .300 .250 .200 .150 .100 .050 .00$

Fig. 6. Evolutionary relationships of taxa. The isolated bacteria with its accession number is indicated by red point

has some debates but is supposed to include a combination of environmental and genetic factors. According to a previous study reported by Xue et al. in 2016, the possibility of dandruff formation is higher due to bacteria (Staphylococcus) than that of fungi. The amount of sebum and water indicated the presence of bacteria ${ }^{5}$. In this study, the morphological, physiological, biochemical, antibiotic, antibacterial, antagonistic and molecular tests were performed after the isolation of bacterial strains for the bacterial identification. In gram staining, isolated bacteria from hair samples showed a purple color, indicating that it's a gram-positive bacterium. Isolated bacteria showed non-motility in SIM medium and did not produce $\mathrm{H}_{2} \mathrm{~S}$ and indole ring. Here, isolated bacteria showed a positive result to Simmons citrate and a negative result for the MacConkey agar test. Kligler Iron Agar (KIA) test may help to differentiate enteric gram-negative bacilli based on the fermentation of carbohydrate and production of $\mathrm{H}_{2} \mathrm{~S}$.

In this study, isolated bacteria showed a positive result to the KIA test, which means the bacteria were glucose fermenters and nonlactose fermenters. The Catalase test is used to identify organisms producing catalase enzymes. By breakdown into water and oxygen gasses, this enzyme detoxifies hydrogen peroxide. The results of bubbles produced during the production of oxygen gas indicate the Catalase test positive. This finding indicates the similarity of the previously reported experiment ${ }^{24}$. The Methyl red test is used to identify the stable acidic end product that confirms mixed acid-fermenting bacteria. In this test, isolated bacteria showed a negative result with a yellow color. Urease test measure the capability of a microorganism to breakdown urea by producing urease enzyme. Isolated bacteria showed a negative result in the present study. There was a similar result reported earlier ${ }^{25}$.

In the antibiotic susceptibility test, 16 antibiotics were used to perform the antibacterial activity of an antibiotic against bacterial isolates responsible for dandruff, using Kirby-Bauer antibiotics (KB test) or discuss susceptibility to diffusion antibiotics. An antibiotic sensitivity test was helpful in finding out the control measures of this disease. The zone of inhibition on a plate identified the sensitivity pattern of the isolated bacteria against the different types of antibiotics ${ }^{26}$. This result showed that isolated bacteria were very sensitive to Kanamycin, Oxytetracycline, Cefotaxime, Cefixime, Nalitic Acid, and Neomycin.

Antimicrobial activities against isolated bacterial species were evaluated in vitro by ten medicinal plants used as extracted material. Isolated bacteria were intermediately resistant to Allium sativum and the increase of that compound increased their sensitivity. These are similar to the findings of some previous studies ${ }^{26-27}$.

In the present study, we find out that the bacterial strain is responsible for the dandruff disease of human hair. And molecular 
identification of bacteria creates an opportunity to identify this pathogen using specific primers. It also provides information for future research to know the facts behind this bacterial pathogenicity.

\section{CONCLUSION}

Human hair dandruff (HDD) is a common, unpleasant scalp disorder that is one of the major concerns for the health-conscious people over the world. In our recent work, we isolated dandruff, causing pathogens from a healthy volunteer, experimented with some major biochemical and molecular characterization to control this disease using some globally available medicinal plants. In the Biochemical test, we proved that isolated bacteria as gram-positive and non-motile, glucose fermented, but lactose non-fermented. In molecular characterization, it confirms the isolated bacterial strain is Staphylococcus aureus that leads to identifying the associated genes or functional group for dandruff pathogenesis. In the antimicrobial test, Staphylococcus aureus shows the highest sensitivity to Allium sativum among all the plant extracts that recommend a new prospect for developing an anti-dandruff compound. Although there were some limitations as we isolated pathogens from a single volunteer, the present study would be helpful for further direction of identification and control of this pathogen with biologically active compounds.

\section{Application of research}

Disease identification, characterization of the pathogen and management of the abovementioned disease will increase the quality and quantity of human hair.

\section{ACKNOWLEDGMENTS}

The authors wish to thank Professor Joarder DNA and Chromosome Research Lab, Dept. of Genetic Engineering and Biotechnology, University of Rajshahi, Bangladesh for providing financial support and other facilities during the whole research work.

\section{CONFLICT OF INTEREST}

The authors declare that there is no conflict of interest.

\section{AUTHORS' CONTRIBUTION}

MAM, MRA, SMZH, and MFH designed the experiments, developed the methodology and prepare the manuscript. MAM, MRA, MFH, and $\mathrm{BS}$ collected the data and carried out the analysis. MRA, MFH, MAI, and MAI assisted with data analysis and manuscript preparation. Finally, MAM, MRA, SMZH, MAI, and MFH carried out manuscript correction according to the journal's comment.

\section{DATA AVAILABILITY}

All datasets generated or analyzed during this study are included in the manuscript.

\section{ETHICS STATEMENT}

Prior to the commencement of the study, the ethical clearance of the study was approved by the Director of the Institute of Biological Sciences (Approval no. IBSC.EC.5.6.18-00122) and ethical committees. In addition, specimens were collected and consent was obtained from patients.

\section{REFERENCES}

1. Ranganathan S, Mukhopadhyay T. Dandruff: the most commercially exploited skin disease. Indian J Dermatol, 2010; 55(2): 130-134. https://doi.org/10.4103/00195154.62734

2. Borda LJ, Wikramanayake TC. Seborrheic dermatitis and dandruff: a comprehensive review. J Clin Investig Dermatol, 2015; 3(2): https://doi.org/10.13188/23731044.1000019

3. Dos Santos R, Dias-Souza M, Effectiveness of five antidandruff cosmetic formulations against planktonic cells and biofilms of dermatophytes. Saudi J Biol Sci, 2017; 24(2): 331-337. https://doi.org/10.1016/j. sjbs.2015.09.033

4. Lakhundi S, Zhang K. Methicillin-resistant Staphylococcus aureus: molecular characterization, evolution, and epidemiology. Clin Microbiol Rev, 2018, 31(4): e00020-18. https://doi.org/10.1128/ CMR.00020-18

5. Xu Z, Wang Z, Yuan C, Liu X, Yang F, Wang T et al. Dandruff is associated with the conjoined interactions between host and microorganisms. Sci. Rep, 2016; 6: 24877. https://doi.org/10.1038/srep24877.

6. Tong SYC, Davis JS, Eichenberger E, Holland TL, Fowler VG, Jr. Staphylococcus aureus infections: epidemiology, pathophysiology, clinical manifestations, and management. Clin Microbiol Rev, 2015; 28(3): 603-661 https://doi.org/10.1128/CMR.00134-14.

7. Taylor T A, Unakal C G. Staphylococcus aureus[M]// StatPearls [Internet]. StatPearls Publishing, 2017. Leong C, Schmid B, Buttafuoco, A, Glatz M \& Bosshard PP. In vitro efficacy of antifungal agents alone and in shampoo formulation against dandruff-associated

\section{FUNDING}

None. 
Malassezia spp. and Staphylococcus spp. International Journal of Cosmetic Science, 2019; 41(3): 221-227. https://doi.org/10.1111/ics.12525

9. Parameswari P, Devika R, Vijayaraghavan P. In vitro anti-inflammatory and antimicrobial potential of leaf extract from Artemisia nilagirica (Clarke) Pamp. Saudi J Biol Sci, 2019; 26(3): 460-463. https:// doi.org/10.1016/j.sjbs.2018.09.005

10. Prescott LM, Harley JP, Klein DA. Microbiology, $5^{\text {th }}$ eds. McGraw-Hill, New York, 2002; 1014.

11. Sherman N, Cappuccino JG. Microbiology: a laboratory manual. 6th eds, 2005; 81: 265-267.

12. Ali MR, Hasan MF, Lia RS, Akter A, Sumi MSE, et al. Isolation and characterization of a canker disease causing pathogen from Citrus aurantifolia and evaluation of its biological control measure. J. Entomol. Zool. Stud, 2017; 5(6): 1526-1532.

13. Hasan SZ, Hossain F, Zaoti ZF, Hasan F, Islam A, Khalekuzzaman, Sikdar B. PCR amplification of DNA sequence related to the $h r p D$ gene of Xanthomonas cucurbitae in leaf spot disease of pumpkin and their antagonism by soil bacteria. Arch. Phytopathol, 2018; 51(5-6):252-66. https://doi.org/10.1080/03235408.2 018.1460923

14. Bergey DH, Holt JG, Noel RK. Bergey's Manual of Systematic Bacteriology 9th Edn, 1994; 1: 1935-2045.

15. Zaoti ZF, Hasan SZ, Hossain MF, Hasan MF et al. Biochemical and Molecular Characterization of Bacterial Wilt Disease of Banana and Evaluation of their Antibiotic Sensitivity. Microbiology Research Journal International, 2017; 22(6): 1-10, 2017. https:// doi.org/10.9734/MRJI/2017/38206

16. Grice EA, Kong HH, Conlan S, Deming CB, Davis J, Young, AC, Bouffard GG, Blakesley RW, Murray PR, Green ED and Turner ML. Topographical and temporal diversity of the human skin microbiome. Science, 2009; 324(5931): 1190-1192. https://doi.org/10.1126/ science. 1171700

17. Bauer A, Kirby W, Sherris JC, Turck M. Antibiotic susceptibility testing by a standardized single disk method. Am J Clin Pathol, 1966; 45(4): 493-496. https://doi.org/10.1093/ajcp/45.4_ts.493
18. Hindi N Chabuck Z. Antimicrobial activity of different aqueous lemon extracts. J appl pharm Sci, 2013; 3: 74.

19. Tchinda CF, Voukeng IK, Beng VP, Kuete V. Antibacterial activities of the methanol extracts of Albizia adianthifolia, Alchornea laxiflora, Laportea ovalifolia and three other Cameroonian plants against multidrug resistant Gram-negative bacteria. Saudi I Biol Sci, 2017; 24(4): 950-955. https://doi.org/10.1016/j. sjbs.2016.01.033

20. Hasan MF, Sikdar B. Screening of antimicrobial, cytotoxic and pesticidal activities of Coccinia grandis (L.) Voigt. J. Microbiol. Biotech. Food Sci, 2016; 5(6): 584-588. https://doi.org/10.15414/jmbfs.2016.5.6.584-588

21. Sneath PHA Sokal RR. Numerical Taxonomy. Freeman, San Francisco, 1973.

22. Tamura K, Nei M, Kumar S. Prospects for inferring very large phylogenies by using the neighbor-joining method. Proceedings of the National Academy of Sciences (USA), 2004; 101: 11030-11035. https://doi. org/10.1073/pnas.0404206101

23. Kumar S, Stecher G, Tamura K. MEGA7: Molecular Evolutionary Genetics Analysis version 7.0 for bigger datasets. Mol. Biol. Evol, 2016; 33:1870-1874. https:// doi.org/10.1093/molbev/msw054

24. Laxminarayan R, Duse A, Wattal C, Zaidi A K, Wertheim $\mathrm{HF}$, et al. Antibiotic resistance the need for global solutions. Lancet Infect Dis, 2013; 13(12): 1057-1098. https://doi.org/10.1016/S1473-3099(13)70318-9

25. Islam MA, Mazumdar RM, Islam S, Alam MJ, Urmee SA. Isolation, Identification and In-Vitro Antibiotic Sensitivity Pattern of Citrus Canker Causing Organism Xanthomonas axonopodis. Advancements in Life Sciences, 2014; 1(4): 215-222.

26. Jorgesen J Turnidge J. Susceptibility Test Methods: Dilution and Disk Diffusion Method. Manual of Clinical Microbiology, 2015; 1253-1273. https://doi. org/10.1128/9781555817381.ch71

27. Verma $\mathrm{V}$, Singh R, Tiwari RK, Srivastava N, Verma A. Antibacterial activity of extracts of Citrus, Allium \& Punica against food borne spoilage. Asian Journal of Plant Science and Research, 2012; 2(4): 503-509. 